\title{
cRGDyK-modified procaine liposome inhibits the proliferation and motility of glioma cells via the ERK/p38MAPK pathway
}

\author{
DEDONG LI ${ }^{1 *}$, JIE GAO $^{2 *}$, CHENYI YANG $^{3}$, BO LI $^{1}$, JIAN SUN $^{1}$, MINGDONG YU $^{1}$, \\ YING WANG $^{1}$, HAIYUN WANG ${ }^{3}$ and YUECHUN LU ${ }^{1}$ \\ ${ }^{1}$ Department of Anesthesiology, Second Hospital of Tianjin Medical University, \\ Tianjin 300211; ${ }^{2}$ Department of Anesthesiology, Tianjin Haihe Hospital, Tianjin 300350; \\ ${ }^{3}$ Department of Anesthesiology, Tianjin Third Central Hospital, Tianjin 300052, P.R. China
}

Received May 7, 2020; Accepted May 27, 2021

DOI: $10.3892 /$ etm.2021.10291

\begin{abstract}
Glioma is a common type of primary tumor in the central nervous system. Glioma has been increasing in incidence yearly and is a serious threat to human life and health. The aim of the present study was to prepare liposomes for enhanced penetration of the blood-brain barrier and targeting of glioma. A procaine-loaded liposome modified with the cyclic pentapeptide cRGDyK (Pro/cRGDyK-L) was designed and developed. The particle size, $\zeta$ potential, encapsulation efficiency, release profile, stability and hemolysis of Pro/cRGDyK-L were characterized in vitro. The targeting and antitumor effects of Pro/cRGDyK-L were also investigated in vitro and in vivo. The results suggested that the cRGDyK peptide significantly facilitated the ability of liposomes to transfer procaine across the $\mathrm{BBB}$ and improved the cellular uptake of procaine by C6 glioma cells. The results further demonstrated that Pro/cRGDyK-L strongly suppressed cell motility, stimulated apoptosis and induced cell cycle arrest. The findings further confirmed that Pro/cRGDyK-L exhibited superior antitumor effects by targeting the ERK/p38MAPK pathway and thereby suppressed tumor growth in mice. In conclusion, the present study indicated the potential of Pro/cRGDyK-L as a means to provide improved therapeutic effects on glioma through the ERK/p38MAPK pathway.
\end{abstract}

\section{Introduction}

Glioma is a common primary tumor of the central nervous system (1). The incidence of glioma is increasing year by year, with an annual growth rate of $\sim 1.2 \%$ (2). Glioma is a serious

Correspondence to: Professor Yuechun Lu, Department of Anesthesiology, Second Hospital of Tianjin Medical University, 23 Pingjiang Road, Tianjin 300211, P.R. China

E-mail: luyuechunmzk@126.com

*Contributed equally

Key words: glioma, cRGDyK, procaine, liposome, ERK/p38MAPK threat to human life and health. Despite the emergence of treatment regimens comprising combined surgery and chemoradiotherapy, the prognosis of patients with malignant glioma has not been markedly improved and the median survival time is only $12-15$ months $(3,4)$. Since glioma usually grows and infiltrates surrounding tissue and its boundary is not clear, it is challenging to remove completely by surgery (5). Therefore, the use of targeted therapy is therapeutically important (6). A variety of targeted drugs have been used clinically or tested for the treatment of glioma in clinical trials; however, the development of more effective therapeutic drugs is necessary in order to improve the prognosis of patients (7).

The antitumor effects and mechanisms of certain anesthetics have been revealed (8). Studies have demonstrated that anesthetics affect the apoptosis, proliferation, metastasis and DNA demethylation of some types of cancer cells (9-11). Anesthetics have exhibited antitumor effects on various malignancies. For example, studies have shown that clinical doses of lidocaine and bupivacaine can induce the apoptosis of MCF-7 breast cancer cells, while dibucaine has a pro-apoptotic effect on HL-60 promyelocytic leukemia cells $(10,11)$. In addition, procaine is able to inhibit the proliferation of CNE-2Z nasopharyngeal carcinoma cells (12).

The p38 MAP kinase (MAPK) participates in a signaling pathway that mediates the response of cells to cytokines and stress (13). The involvement of the ERK/p38 MAPK pathway in the progression of several types of cancer, including glioma, has already been revealed (14). Several oncogenes have been shown to affect the progression and metastasis of multiple types of cancer, including breast, lung and gastric cancer, through this pathway, and numerous drugs targeting the ERK/p38MAPK pathway have been developed or are in clinical trials (15).

Strategies for the effective delivery of anesthetics, such as procaine, into the brain are of great interest for the treatment of glioma. Researchers have attempted to increase the penetration of the blood-brain barrier (BBB) by drugs, and active targeting is proving to be an attractive approach for the enhancement of glioma-targeting ability using specific ligands $(16,17)$. The pentapeptide cyclic (arginine-glycine-aspartic acid-tyrosine-lysine) (cRGDyK) is a promising ligand $(18,19)$ for targeting the integrin $\alpha_{v} \beta_{3}$ receptor, which is highly expressed 
on the surface of multiple types of cancer cells, including C6 glioma and MDA-MB-231 breast cancer cells (20-22). As the expression of integrin $\alpha_{v} \beta_{3}$ on normal cells is limited, it is an attractive receptor for glioma targeting. In addition, the integrin receptor is highly expressed on cerebral capillary endothelial cells (23). Therefore, the cRGDyK peptide may have the ability to cross the BBB and target glioma.

To verify the aforementioned functions of cRGDyK peptide and investigate the antitumor mechanism of procaine, a procaine-loaded liposome modified with cRGDyK (Pro/cRGDyK-L) was developed in the present study. The ability of the cyclic peptide to enhance the penetration of the BBB by procaine and improve cellular uptake was investigated. Additionally, the inhibitory effects of Pro/cRGDyK-L on cell migration, apoptosis and cell cycle arrest were evaluated. Furthermore, whether Pro/cRGDyK-L targets the ERK/p38 MAPK pathway and inhibits tumor growth in vivo was analyzed.

\section{Materials and methods}

\section{Chemistry}

Synthesis of $(3 S, 10 R, 13 R, 17 R)-10,13$-dimethyl-17- $((R)$ -6-methylheptan-2-yl)-2,3,4,7,8,9,10,11,12,13,14,15, 16,17tetradecahydro-1H-cyclopenta[a]phenanthren-3-yl 4-methyl benzenesulfonate (compound 2). To a solution of cholesterol (compound $1 ; 1.00 \mathrm{~g}, 2.59 \mathrm{mmol})$ in pyridine $(5 \mathrm{ml})$, a solution of $p$-toluenesulfonyl chloride $(0.74 \mathrm{~g}, 3.88 \mathrm{mmol})$ in pyridine $(5 \mathrm{ml})$ was added. After stirring the mixture for $10 \mathrm{~h}$ at $50^{\circ} \mathrm{C}$, the solvent was removed and the residue was redissolved in ethyl acetate $(20 \mathrm{ml})$. The mixture was washed with $1 \mathrm{~mol} / 1$ $\mathrm{HCl}$ and saturated $\mathrm{NaCl}$. The solvent was then removed to yield compound $2(1.19 \mathrm{~g}, 85 \%)$, which was used for the next step without further purification. Melting point: $127-129^{\circ} \mathrm{C}$. High-resolution mass spectrometry (HRMS): Electrospray ionization $\left(\mathrm{ESI}^{+}\right)$calculated for $\mathrm{C}_{34} \mathrm{H}_{52} \mathrm{O}_{3} \mathrm{SNa}[\mathrm{M}+\mathrm{Na}]^{+}$, 563.3535; found, 563.3532. Elemental analysis: Calculated, C, 75.51; H, 9.69; S, 5.93; found, C, 75.43; H, 9.78; S, 6.11.

Synthesis of 23-(((3R,10R,13R,17R)-10,13-dimethyl-17((R)-6-methylheptan-2-yl)-2,3,4,7,8,9,10,11,12,13,14,15,16, 17-tetradecahydro-1H-cyclopenta[a]phenanthren-3-yl)oxy)3,6,9,12,15,18,21-heptaoxatricosan-1-ol (compound 3). To a solution of compound $2(1.00 \mathrm{~g}, 1.85 \mathrm{mmol})$ in dioxane $(15 \mathrm{ml})$ was added octaethylene glycol $(6.85 \mathrm{~g}, 18.49 \mathrm{mmol})$, and the reaction mixture was refluxed for $20 \mathrm{~h}$. The solvent was then removed and the residue was redissolved in dichloromethane $\left(\mathrm{CH}_{2} \mathrm{Cl}_{2} ; 30 \mathrm{ml}\right)$. The mixture was washed with saturated $\mathrm{NaCl}$. After removing the $\mathrm{CH}_{2} \mathrm{Cl}_{2}$, the residue was purified by chromatography to give compound $3(0.66 \mathrm{~g}, 48 \%)$ as a colorless oil. HRMS: $\left(\mathrm{ESI}^{+}\right)$calculated for $\mathrm{C}_{43} \mathrm{H}_{78} \mathrm{O}_{9} \mathrm{Na}[\mathrm{M}+\mathrm{Na}]^{+}$, 761.5544; found, 761.5540. Elemental analysis: Calculated, C, 69.88; H, 10.64; found, C, 69.76; H, 10.79 .

Synthesis of tert-butyl 26-(( $3 R, 10 R, 13 R, 17 R)-10$, 13-dimethyl-17-((R)-6-methylheptan-2-yl)-2,3,4,7,8,9,10,11, 12,13,14,15,16,17-tetradecahydro-1H-cyclopenta[a]phenanthren-3-yl)oxy)-3,6,9,12,15,18,21,24-octaoxahexacosanoate (compound 4$)$. To a solution of compound $3(0.50 \mathrm{~g}, 0.68 \mathrm{mmol})$ in toluene $(10 \mathrm{ml})$ was added $50 \% \mathrm{NaOH}$ aqueous solution $(5 \mathrm{ml})$ at $0^{\circ} \mathrm{C}$. Then, tert-butyl bromoacetate $(0.16 \mathrm{ml}$, $1.02 \mathrm{mmol}$ ) and tetra- $n$-butylammonium hydrogen sulfate
(24 mg, $0.07 \mathrm{mmol}$ ) were added to the solution and the mixture was stirred for $20 \mathrm{~h}$ at ambient temperature. The organic layer was separated and washed with saturated $\mathrm{NaCl}$. After removing the solvent, the residue was purified by chromatography to give compound $4(0.44 \mathrm{~g}, 75 \%)$ as a colorless oil. HRMS: $\left(\mathrm{ESI}^{+}\right)$calculated for $\mathrm{C}_{49} \mathrm{H}_{88} \mathrm{O}_{11} \mathrm{Na}[\mathrm{M}+\mathrm{Na}]^{+}, 875.6224$; found, 875.6227. Elemental analysis: Calculated, C, 68.98; H, 10.40; found, C, 68.85; H, 10.50 .

Synthesis of 26-(((3R,10R,13R,17R)-10,13-dimethyl-17((R)-6-methylheptan-2-yl) -2,3,4,7,8,9,10,11,12,13,14,15,16, 17-tetradecahydro-1H-cyclopenta[a]phenanthren-3-yl)oxy)-3, $6,9,12,15,18,21,24$-octaoxahexacosanoic acid (compound 5). To a solution of compound $4(1.50 \mathrm{~g}, 1.76 \mathrm{mmol})$ in toluene $(20 \mathrm{ml})$ was added $p$-toluenesulfonic acid $(60 \mathrm{mg}, 0.35 \mathrm{mmol})$, and the mixture was heated to reflux for $10 \mathrm{~h}$. The solvent was removed and the residue was purified by chromatography to give compound $5(1.23 \mathrm{~g}, 88 \%)$ in the form of a yellow oil. HRMS: (ESI ${ }^{+}$) calculated for $\mathrm{C}_{45} \mathrm{H}_{80} \mathrm{O}_{11} \mathrm{Na}[\mathrm{M}+\mathrm{Na}]^{+}, 819.5598$; found, 819.5595. Elemental analysis: Calculated, C, 67.81; H, 10.12; found C, 67.89; H, 10.03 .

Synthesis of 2,5-dioxopyrrolidin-1-yl 26-(( $(3 R, 10 R, 13 R$, 17R)-10,13-dimethyl-17-((R)-6-methylheptan-2-yl) -2,3,4,7,8, $9,10,11,12,13,14,15,16,17$ - tetradecahydro-1H-cyclopenta[a] phenanthren-3-yl)oxy)-3,6,9,12,15,18,21,24-octaoxahexacosanoate (compound 6$)$. To a solution of compound $5(0.80 \mathrm{~g}$, $1.00 \mathrm{mmol}$ ) in tetrahydrofuran (THF; $10 \mathrm{ml}$ ) was added $N$-hydroxysuccinimide (NHS; $0.35 \mathrm{~g}, 3.00 \mathrm{mmol}$ ) and $N, N$-dicyclohexylcarbodiimide (DCC; $0.62 \mathrm{~g}, 3.00 \mathrm{mmol}$ ), and the mixture was stirred at room temperature for $20 \mathrm{~h}$. After removing the THF, the residue was purified by chromatography to give compound $6(0.58 \mathrm{~g}, 65 \%)$ as a yellow oil. HRMS: (ESI ${ }^{+}$calculated for $\mathrm{C}_{49} \mathrm{H}_{83} \mathrm{O}_{13} \mathrm{Na}[\mathrm{M}+\mathrm{Na}]^{+}, 916.5762$; found, 916.5766. Elemental analysis: Calculated, C, 65.82; $\mathrm{H}, 9.36 ; \mathrm{N}, 1.57$; found, $\mathrm{C}, 65.88 ; \mathrm{H}, 9.45 ; \mathrm{N}, 1.42$.

Synthesis of $2-((2 R, 5 S, 8 R, 11 R)-8-(1-(((3 R, 10 R, 13 R, 17 R)-$ 10,13-dimethyl-17-((R)-6-methylheptan-2-yl)-2,3,4,7,8,9, 10,11,12,13,14,15,16,17-tetradecahydro-1H-cyclopenta[a] phenanthren-3-yl)oxy)-26-oxo-3,6,9,12,15,18,21,24-octaoxa27-azahentriacontan-31-yl)-11-(3-guanidinopropyl)- 5-(4-hydr oxybenzyl)-3,6,9,12,15-pentaoxo-1,4,7,10, 13-pentaazacyclopentadecan-2 -yl)acetic acid (cRGDyK-modified ligand). To a solution of compound $6(0.20 \mathrm{~g}, 0.22 \mathrm{mmol})$ and cRGDyK (0.14 g, $0.22 \mathrm{mmol})$ in $10 \mathrm{ml}$ dimethylformamide was added triethylamine $(0.16 \mathrm{ml}, 1.12 \mathrm{mmol})$, and the mixture was stirred for $5 \mathrm{~h}$ at room temperature. The reaction was terminated by adding saturated $\mathrm{NaCl}(50 \mathrm{ml})$ and the mixture was extracted with $\mathrm{CH}_{2} \mathrm{Cl}_{2}$ three times. After removing $\mathrm{CH}_{2} \mathrm{Cl}_{2}$, the residue was purified by chromatography to provide the cRGDyK-modified ligand $(0.15 \mathrm{~g}, 48 \%)$ as a yellow oil. HRMS: $\left(\mathrm{ESI}^{+}\right)$calculated for $\mathrm{C}_{72} \mathrm{H}_{119} \mathrm{~N}_{9} \mathrm{O}_{18} \mathrm{Na}[\mathrm{M}+\mathrm{Na}]^{+}$, 1,420.8571; found, 1,420.8576. Elemental analysis: Calculated, C, 61.82; H, 8.58; N, 9.01; found, C, 61.89; H, 8.65; N, 9.14.

Preparation and characterization of liposomes. The procaine-loaded liposomes were prepared using the thin film hydration method (24). The component ratio was optimized as follows: i) conventional liposome (L), soybean phosphatidyl choline (Shanghai Pharmaceutical Co., Ltd.)/cholesterol molar ratio 62:33; ii) cRGDyK-modified liposome (cRGDyK-L), SPC/cholesterol/ligand molar ratio 62:33:3. In brief, all the 
lipid materials were dissolved in a mixed solvent comprising $\mathrm{CH}_{2} \mathrm{Cl}_{2}$ and methanol $(2: 1 \mathrm{v} / \mathrm{v})$, and then heated to $37^{\circ} \mathrm{C}$ on a rotary evaporator to remove the solvent and form a thin film. After drying in a vacuum for $10 \mathrm{~h}$, the film was hydrated with PBS ( $\mathrm{pH} \mathrm{7.4)} \mathrm{at} 20^{\circ} \mathrm{C}$ for $30 \mathrm{~min}$ and then sonicated intermittently at $80 \mathrm{~W}$ for $80 \mathrm{sec}$ to obtain the liposomes. An appropriate amount of procaine (weight ratio, 1:30) or 1,2-dioleoyl-sn-glycero-3-phosphoethanolamine-N-carboxyfluorescein (CFPE) (final concentration, $20 \mu \mathrm{g} / \mathrm{ml}$ ) was added to the solution of lipid liposomes before removing the solvent to prepare procaine-loaded liposomes (Pro/L and Pro/cRGDyK-L) or CFPE-labeled liposomes (CFPE/L and CFPE/cRGDyK-L).

The entrapment efficiency [EE (\%)] and drug loading efficiency [DL (\%)] of procaine were determined by high performance liquid chromatography (HPLC). The detection was performed using an Agilent 1200 HPLC system (Agilent Technologies, Inc.) with an Ultimate LP-C18 column (4.6x250 mm, $5 \mu \mathrm{m}$; Sepax Technologies, Inc.) at $25^{\circ} \mathrm{C}$. The mobile phase comprised water and methanol $(68: 32 \mathrm{v} / \mathrm{v})$ with a flow rate of $1.0 \mathrm{ml} / \mathrm{min}$. For testing, $10 \mu \mathrm{l}$ procaine-containing sample was injected and the detection wavelength was $290 \mathrm{~nm}$. The EE (\%) and DL (\%) were calculated according to the following equations: $\mathrm{EE}(\%)=$ weight of encapsulated procaine / total weight of procaine, and DL $(\%)=$ weight of encapsulated procaine / total weight of liposome. In addition, the size and $\zeta$ potential of Pro/L and Pro/cRGDyK-L were detected using a Malvern Zetasizer Nano ZS90 (Malvern Panalytical).

Release by Pro/L and Pro/cRGDyK-L in vitro. The release behavior of procaine from the Pro/L and Pro/cRGDyK-L liposomes was evaluated via dialysis. The release behavior of procaine from free procaine was also analyzed as a control. Briefly, the liposomes or free procaine were put into a dialysis bag (molecular weight cut-off, 8,000-14,000 Da) with $50 \mathrm{ml}$ PBS containing $0.1 \%$ Tween $80(\mathrm{v} / \mathrm{v})$ as release medium. The bags were then shaken at $37^{\circ} \mathrm{C}$ with gentle oscillation (45 rpm). At predetermined time points between 0 and $48 \mathrm{~h}, 0.1 \mathrm{ml}$ sample was taken out and replaced with fresh medium. Then, the amount of procaine was tested using the aforementioned HPLC method.

Stability of Pro/L and Pro/cRGDyK-L in vitro. The stability of the Pro/L and Pro/cRGDyK-L liposomes was determined by investigating turbidity variations in the presence of fetal bovine serum (FBS, Gibco; Thermo Fisher Scientific, Inc.). In general, each of the liposome formulations was mixed with an equal volume of FBS and then maintained at $37^{\circ} \mathrm{C}$ with continuous shaking $(50 \mathrm{rpm})$. The transmittance at $750 \mathrm{~nm}$ was measured between 0 and $48 \mathrm{~h}$ using a microplate reader (Bio-Rad model 550; Bio-Rad Laboratories, Inc.) and was evaluated relative to the transmittance of PBS, which was defined as $100 \%$.

Hemolysis assays. A female BALB/c mouse (22 g; age, 4 weeks) was anesthetized by the injection of pentobarbital sodium intraperitoneally at a dose of $50 \mathrm{mg} / \mathrm{kg}$. The mouse was kept in a $20^{\circ} \mathrm{C}$ environment with $40-60 \%$ humidity and a 12-h light/dark cycle and free access to food and water.
Fresh mouse blood $(0.1 \mathrm{ml})$ was collected from the orbit and centrifuged at $2,000 \mathrm{x}$ g for $5 \mathrm{~min}\left(4^{\circ} \mathrm{C}\right)$. The supernatant was discarded and the precipitated red blood cells were washed with PBS until the supernatant was colorless. The cells were then re-suspended in PBS to a concentration of $2 \%(\mathrm{w} / \mathrm{v})$. Afterwards, the Pro/L and Pro/cRGDyK-L liposomes were diluted with PBS to prepare liposome samples with a range of lipid concentrations (10, 25, 50, 100, 200 and $400 \mathrm{nM})$. Subsequently, the liposome sample $(0.4 \mathrm{ml})$ was mixed with the suspension of red blood cells $(0.1 \mathrm{ml})$ and the mixture was maintained at $37^{\circ} \mathrm{C}$ for $2 \mathrm{~h}$ with gentle shaking (50 rpm). After centrifuging at $6,000 \mathrm{x} \mathrm{g}$ for $10 \mathrm{~min}\left(4^{\circ} \mathrm{C}\right)$, the absorbance of the supernatant at $540 \mathrm{~nm}\left(\mathrm{~A}_{540}\right)$ was measured using a microplate reader. The hemolysis rate of each sample was calculated as follows: Hemolysis $(\%)=\left[\left(\mathrm{A}_{540}\right.\right.$ sample $-\mathrm{A}_{540}$ negative $) /$ ( $\mathrm{A}_{540}$ positive - $\mathrm{A}_{540}$ negative)] x100. The absorbance of PBS and Triton X-100 mixed with the cell suspension were defined as 0 and $100 \%$, respectively.

\section{3-(4,5-Dimethylthiazol-2-yl)-2,5-diphenyl tetrazolium} bromide (MTT) assay. A cytotoxicity assay was performed using a standard MTT-based colorimetric assay. In brief, bEnd.3 and C6 cells were bought from American Type Culture Collection and cultured in Dulbecco's modified Eagle's medium (DMEM, Gibco; Thermo Fisher Scientific, Inc.) supplemented with $10 \% \mathrm{FBS}$ at $37^{\circ} \mathrm{C}$ in a humidified incubator containing $5 \% \mathrm{CO}_{2}$. The cells were seeded into 96-well plates. In each well, cells at a density of $\sim 5 \times 10^{3}$ cells/well were cultured for $24 \mathrm{~h}$. Fresh medium with procaine, Pro/L and Pro/cRGDyK-L was applied in which the procaine concentration ranged from 0.01 to $10 \mathrm{mM}$. The cells were incubated for another $24 \mathrm{~h}$ at $37^{\circ} \mathrm{C}$, and then MTT $(5 \mathrm{mg} / \mathrm{ml})$ was added to each well with further culturing for another $4 \mathrm{~h}$ at $37^{\circ} \mathrm{C}$. Next, the cells were lysed using $200 \mu \mathrm{l}$ DMSO and the absorbance at $490 \mathrm{~nm}\left(\mathrm{~A}_{490}\right)$ was read using a microplate reader. Survival percentages were calculated using the following equation: Survival $(\%)=\left[\left(\mathrm{A}_{490}\right.\right.$ treated cells $) /\left(\mathrm{A}_{490}\right.$ control cells $\left.)\right] \mathrm{x} 100$.

Transendothelial migration in an in vitro BBB model. Millicell ${ }^{\circledR}$ Hanging Cell Culture Inserts (Corning, Inc.) were used to build an in vitro $\mathrm{BBB}$ model as described in a previous study (25). Briefly, bEnd.3 cells were maintained in DMEM with $10 \%$ FBS and seeded on 6-well plate at a density of $1 \times 10^{6}$ cells/well and incubated for 7 days at $37^{\circ} \mathrm{C}$. The transendothelial electric resistance (TEER) of the BBB model was measured using a Millicell ERS volt-ohm meter (EMD Millipore). Only the bEnd.3 monolayers with a TEER $>200 \Omega$ were used for further experiments. In addition, C6 cells were plated on another 6-well plate. After transferring the cell culture inserts with bEnd.3 monolayers into the plates containing C6 cells, the cells were co-cultured for another $24 \mathrm{~h}$ at $37^{\circ} \mathrm{C}$. Subsequently, the CFPE-labeled liposomes (CFPE/L and CFPE/cRGDyK-L; final concentration, $2 \mu \mathrm{g} / \mathrm{ml}$ ) were added to the cell culture inserts (donor chamber) of the BBB model and incubated for $4 \mathrm{~h}$. After this, the bEnd. 3 and C6 cells were each washed with cold PBS three times, trypsinized and resuspended in $0.5 \mathrm{ml}$ PBS. The fluorescent intensity of the two types of cells was measured using a flow cytometer (Cytomics FC500; Beckman Coulter, Inc.) and corresponding software. 
Wound healing assays. To determine the effects of the liposomal formulations on cell migration ability, the wound healing assay was performed. Briefly, C6 cells (confluence, $100 \%$ ) treated with Pro/L or Pro/cRGDyK-L were wounded by scraping with a pipette tip, and the detached cells were washed away. Subsequently, the cells were cultured with serum-free DMEM (Gibco; Thermo Fisher Scientific, Inc.) to stimulate wound healing. Photographic images were captured using an Olympus light microscope at $0 \mathrm{~h}$ and $24 \mathrm{~h}$ later to evaluate the migration of the cells (cat. no. CKX53; Olympus Corporation). The images were then analyzed by ImageJ 8.0 software (National Institutes of Health).

Transwell assays. A total of $1 \times 10^{4}$ C6 cells treated with either Pro/L or Pro/cRGDyK-L were seeded in the upper chamber of Transwell plates in DMEM. The upper cells were induced to migrate toward the bottom chamber which contained DMEM plus $10 \% \mathrm{FBS}$ at $37^{\circ} \mathrm{C}$ for $24 \mathrm{~h}$. Then, the cells were stained with $0.2 \%$ crystal violet for $20 \mathrm{~min}$ at $25^{\circ} \mathrm{C}$. Transwell migration was determined as the percentage of input cells minus the percentage of cells migrating to the medium alone (baseline). A light microscope (cat. no. IX71; Zeiss AG) was used for imaging at a magnification of $x 20$. The images were then analyzed by ImageJ 8.0 software (National Institutes of Health).

Cell cycle assays. Flow cytometric analysis was performed to determine the cell cycle distribution of C6 cells. Following treatment with Pro/L or Pro/cRGDyK-L (1 mM calculated as Pro) at $37^{\circ} \mathrm{C}$ for $24 \mathrm{~h}$, the $\mathrm{C} 6$ glioma cells $\left(4 \times 10^{5}\right)$ were washed with PBS and fixed with pre-cooled $70 \%$ ethanol at $-20^{\circ} \mathrm{C}$ for $30 \mathrm{~min}$. Following centrifugation $(450 \mathrm{x} \mathrm{g})$ at $4^{\circ} \mathrm{C}$ for $5 \mathrm{~min}$ and washing with $\mathrm{PBS}$, the cells were stained with $500 \mu \mathrm{l}$ propidium iodide (PI; $50 \mu \mathrm{g} / \mathrm{ml}$; Thermo Fisher Scientific, Inc.), followed by DNA content analyses using a flow cytometer (Cytomics FC500; Beckman Coulter, Inc.) and corresponding software. The percentage of cells in the G1, S and G2/M phases was calculated and analyzed.

Cell apoptosis assays. Cell apoptosis was evaluated using Annexin V-FITC and PI staining (Sangon Biotech Co., Ltd.). Following treatment of the $\mathrm{C} 6$ glioma cells with Pro/L or Pro/cRGDyK-L (0-10 mM calculated as Pro) at $37^{\circ} \mathrm{C}$ for $48 \mathrm{~h}$, the cells were centrifuged $(200 \mathrm{x} \mathrm{g})$ at $4^{\circ} \mathrm{C}$ for $3 \mathrm{~min}$ and washed with PBS. Subsequently, the cells were re-suspended in $100 \mu \mathrm{l}$ binding buffer with $5 \mu \mathrm{l}$ Annexin V-FITC and incubated at room temperature for $10 \mathrm{~min}$. Then, $5 \mu \mathrm{l}$ PI solution was added and the cells were incubated for another 5 min at room temperature. The proportion of apoptotic cells was analyzed using a flow cytometer (Cytomics FC500; Beckman Coulter, Inc.) and corresponding software.

Immunoblot assay. Following treatment with Pro/L or Pro/cRGDyK-L (1 mM calculated as Pro) at $37^{\circ} \mathrm{C}$ for $24 \mathrm{~h}$, and protein determination was performed using the $\mathrm{BCA}$ method. Protein samples $(10 \mu \mathrm{g} /$ per lane) were separated on $10 \%$ SDS-PAGE gels and transferred onto PVDF membranes $(250 \mathrm{~mA}, 2 \mathrm{~h})$. The proteins were transferred onto PVDF membranes, which were then blocked with $5 \%$ milk in TBS with $0.05 \%$ Tween 20 at $25^{\circ} \mathrm{C}$ for $2 \mathrm{~h}$. The
PVDF membranes were subsequently treated with primary antibodies targeting the following proteins: Phosphorylated (p-)ERK1/2 (ERK1 p-T202 + ERK2 p-T185; ab50011; 1:1,000 dilution; Abcam), ERK1/2 (ab17942; 1:1,000 dilution; Abcam), p-p38MAPK (1:500; cat. no. ab4822; Abcam), p38MAPK (1:500; cat. no. ab170099; Abcam) and $\beta$-actin (1:3,000; cat. no. ab8226; Abcam) at room temperature for $2 \mathrm{~h}$. The membranes were then incubated with rabbit or mouse HRP-conjugated secondary antibodies (both 1:5,000; cat. nos. ab6271 and ab6728; both Abcam) at room temperature for $1 \mathrm{~h}$. Protein signals were visualized via the use of an ECL kit Novex $^{\mathrm{TM}}$ ECL Chemiluminescent Substrate Reagent kit; Thermo Fisher Scientific, Inc.) and visualized by ImageJ 8.0 software (National Institutes of Health).

Antitumor activity in vivo. All animal experiments in this study, including the extraction of blood from mice in the hemolysis assay, were approved by the Laboratory Animal Ethics Committee of the Second Hospital of Tianjin Medical University. A total of 18 female BALB/c nude mice (4 weeks old; weight 18-20 g) were acquired from the Animal Core Facility. For the tumor growth assay, $1 \times 10^{7}$ C6 cells were mixed with Matrigel (BD Biosciences) in a 2:1 ratio and subcutaneously implanted into the nude mice to induce tumors for 7 days. To detect the in vivo antitumor effects of procaine and its liposomal formulations on glioma xenografts, the mice were divided into 3 groups ( $n=6 /$ group), and procaine, Pro/L and Pro/cRGDyK-L were administered at a dose of $10 \mathrm{mg} / \mathrm{kg}$, calculated as procaine, via intravenous injection every 3 days. After 12 days of treatment, all the mice were sacrificed by cervical dislocation, and the tumors were isolated from the mice and weighed.

Statistical analysis. All data are presented as the mean \pm standard deviation $(n=3)$. The statistical analyses were conducted using GraphPad Prism 6.0 (GraphPad Software, Inc.). Unpaired Student's t-test was used for statistical comparisons between two groups. Statistical comparisons were performed by one-way analysis of variance for multiple groups followed by Tukey's post hoc tests. $\mathrm{P}<0.05$ was considered to indicate a statistically significant difference.

\section{Results}

Chemistry. The synthetic pathway of the cRGDyK-modified ligand is outlined in Fig. 1. Briefly, cholesterol was esterified with $p$-toluenesulfonyl chloride in pyridine, followed by etherification with octaethylene glycol. Then, a Williamson etherification reaction was conducted with tert-butyl bromoacetate in the mixed solvent of $50 \% \mathrm{NaOH} /$ toluene. Subsequently, the tert-butyl ester was hydrolyzed in the presence of $p$-toluenesulfonic acid to obtain the free acid, which was then reacted with NHS/DCC to form an active ester. Finally, condensation of the peptide cRGDyK with the active ester produced the cRGDyK-modified ligand.

Characterization of liposomes. An appropriate size and uniform distribution are critical for procaine-loaded liposomes to cross the BBB and target glioma. The mean diameters and polydispersity index (PDI) were detected through dynamic 
Table I. Characterization of Pro/L and Pro/cRGDyK-L.

\begin{tabular}{lccccc}
\hline Liposomes & Size $(\mathrm{nm})$ & PDI & EE $(\%)$ & DL $(\%)$ & $\zeta$ potential $(\mathrm{mV})$ \\
\hline Pro/L & $107.51 \pm 8.4$ & $0.195 \pm 0.052$ & $85.77 \pm 3.97$ & $2.81 \pm 0.34$ & $-4.88 \pm 0.39$ \\
Pro/cRGDyK-L & $114.23 \pm 6.1$ & $0.198 \pm 0.077$ & $86.97 \pm 5.24$ & $2.84 \pm 0.55$ & $-7.91 \pm 0.64$ \\
\hline
\end{tabular}

Results are presented as the mean \pm standard deviation $(\mathrm{n}=3)$. Pro, proline; L, conventional liposome; cRGDyK-L, cRGDyK-modified liposome; PDI, polydispersity index; EE, entrapment efficiency; DL, drug loading efficiency.<smiles>CC(C)CCCC1CCC2C(CCC3(C)C2C=CC2CC(O)CCC23)C1CCCC(C)C</smiles>

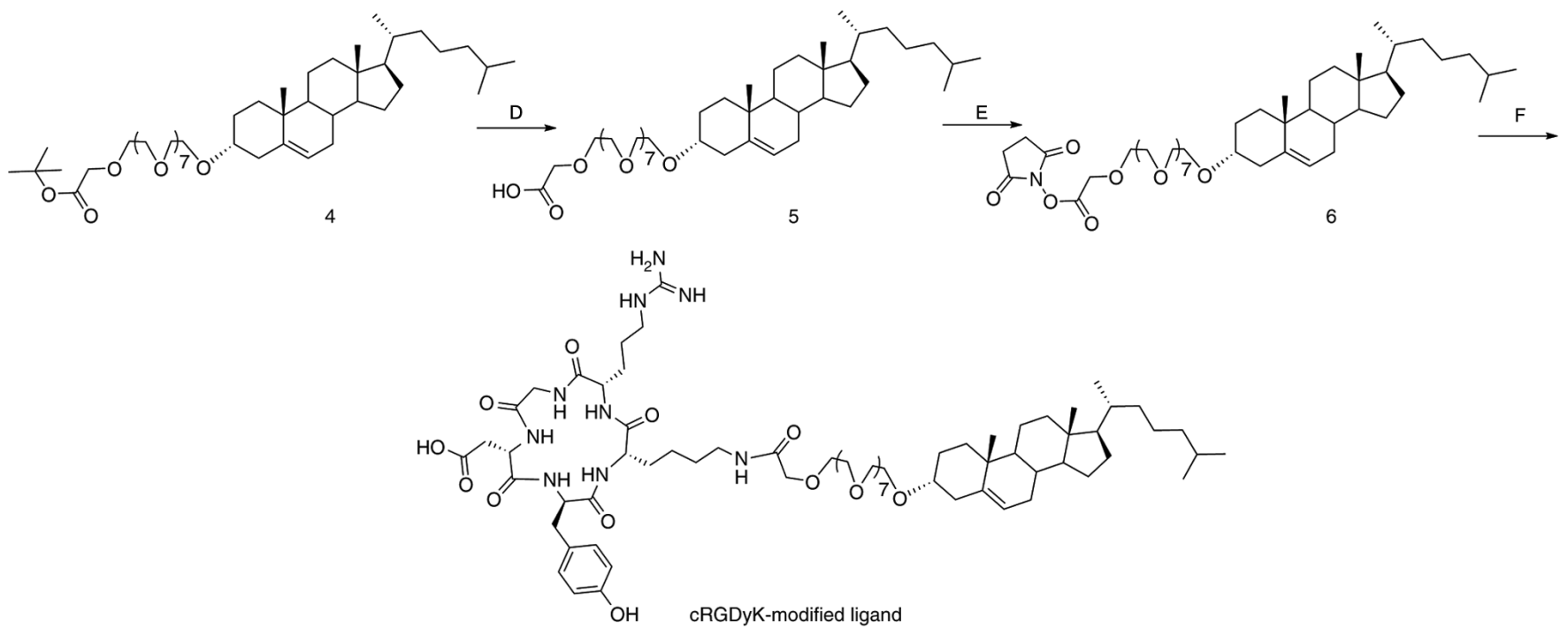

Figure 1. Synthesis of cRGDyK-modified ligand. The reagents and conditions were as follows: (A) TsCl, pyridine, $50^{\circ} \mathrm{C}, 10 \mathrm{~h}$; (B) octaethylene glycol, dioxane, reflux, $20 \mathrm{~h}$; (C) tert-butyl bromoacetate, $n$-butylammonium hydrogensulfate, $50 \% \mathrm{NaOH}$, toluene, room temperature, $20 \mathrm{~h}$; (D) TsOH, toluene, reflux, $10 \mathrm{~h}$; (E) N-hydroxysuccinimide, $N, N$-dicyclohexylcarbodiimide, tetrahydrofuran, room temperature, $20 \mathrm{~h}$; (F) cRGDyK, triethylamine, $N, N$-dimethylformamide, room temperature, $5 \mathrm{~h}$. Ts, $p$-toluenesulfonyl.

light scattering, and the results indicated that the liposomes had a suitable size $(107$ or $114 \mathrm{~nm})$ and PDI $(<0.2)$. Furthermore, the data in Table I also show that the EE (\%) of the liposomes was $>85 \%$ and the DL $(\%)$ was $\sim 2.8 \%$. Also, the weak negative $\zeta$ potential (-7.91) of Pro/cRGDyK-L should decrease absorption by the reticuloendothelial system and the immune response.

An in vitro release assay of the liposomes was used to mimic drug release behavior in vivo and evaluate the entrapment, membrane flexibility and integrity, and affinity of the liposomal carrier systems. The results revealed that procaine from free procaine exhibited fast release, with $\sim 75 \%$ procaine being released in $10 \mathrm{~h}$ (Fig. 2A). However, the two procaine-loaded liposomes released $\sim 40 \%$ of the loaded procaine within $10 \mathrm{~h}$, and the release rate was slow thereafter. Neither of the two liposomes exhibited an initial burst release pattern.

The stability of the liposomes Pro/L and Pro/cRGDyK-L under physiological conditions is critical for their application in vivo. In the stability assay, the transmittances of the two liposome formulations were $>90 \%$, with no marked variation between formulations during the 48-h culture in FBS (Fig. 2B). The results suggest that Pro/L and Pro/cRGDyK-L have adequate stability, which is important for further investigation in vivo. The hemocompatibility of Pro/L and Pro/cRGDyK-L was evaluated by a hemolysis assay, and the results indicated that the two liposome formulations did not induce an excessive increase in hemoglobin release at phospholipid concentrations of $\geq 400 \mathrm{nM}$ (Fig. 2C), which implies that they have acceptable biosafety.

MTT assay. The cytotoxicity of the liposomes to bEnd.3 and C6 cells was evaluated using an MTT assay. As shown in Fig. 3A, free procaine exhibited a greater cytotoxic effect than the procaine-loaded liposomes on the C6 cells, because the free drugs could directly enter the cells by passive diffusion, without a drug-release process. In addition, Pro/cRGDyK-L 

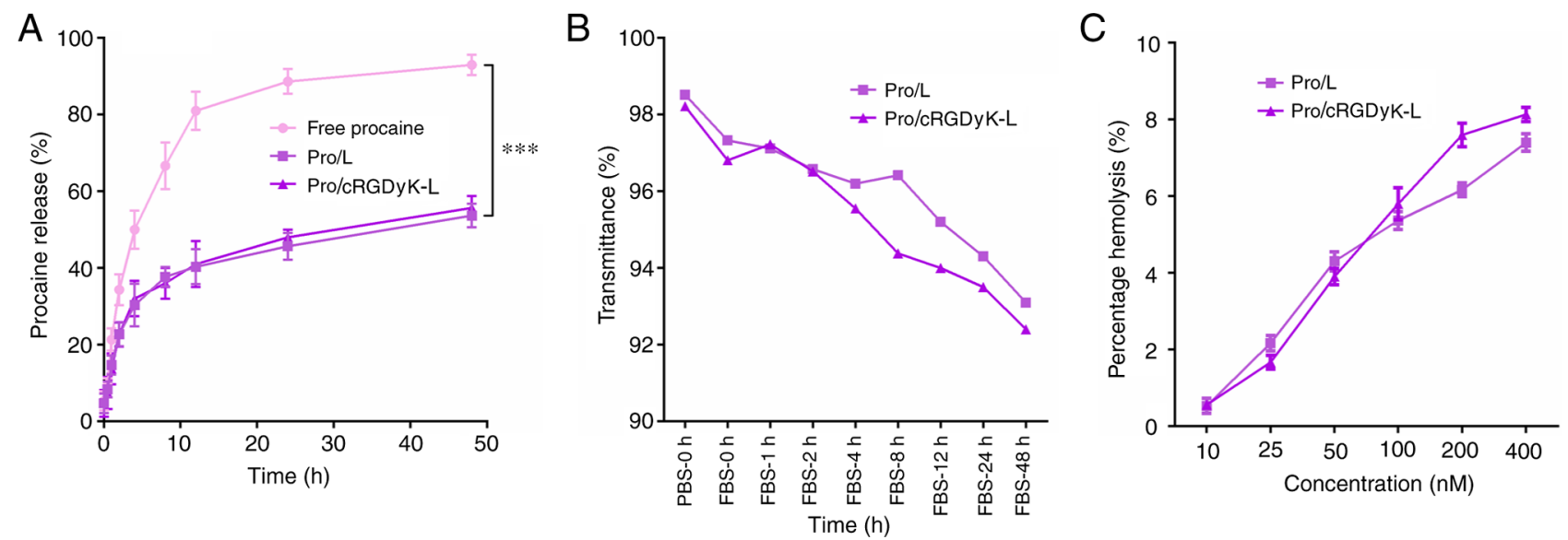

Figure 2. Characterization of release profiles, stability and hemolysis for procaine formulations. (A) Procaine release profiles for free procaine, Pro/L and Pro/cRGDyK-L in PBS (pH 7.4) containing 0.1\% Tween 80 over 48 h. (B) Variations in the transmittance of Pro/L and Pro/cRGDyK-L in 50\% FBS (C) Hemolysis percentage for Pro/L and Pro/cRGDyK-L. Results are presented as the mean \pm standard deviation $(\mathrm{n}=3)$. ${ }^{* * *} \mathrm{P}<0.001$. Pro, procaine; L, conventional liposome; cRGDyK-L, cRGDyK-modified liposome; FBS, fetal bovine serum.
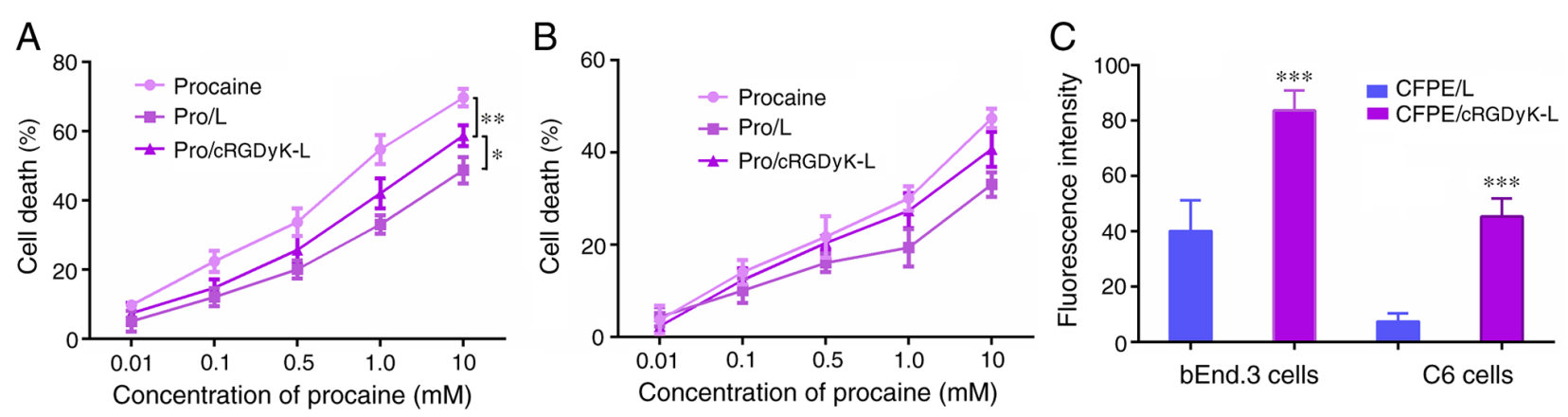

Figure 3. Cytotoxicity and cellular uptake of liposomal formulations. Cytotoxicity of procaine formulations in (A) C6 cells and (B) bEnd.3 cells. (C) Uptake of CFPE-labeled liposomes by bEnd. 3 cells and $\mathrm{C} 6$ cells in an in vitro blood-brain barrier model. ${ }^{*} \mathrm{P}<0.05,{ }^{, * *} \mathrm{P}<0.01,{ }^{* * * *} \mathrm{P}<0.001$. Results are presented as the mean \pm standard deviation $(\mathrm{n}=3$ ). Pro, procaine; L, conventional liposome; cRGDyK-L, cRGDyK-modified liposome; CFPE, 1,2-dioleoyl-sn-glycero-3-phosphoethanolamine-N-carboxyfluorescein.

had a stronger antiproliferative effect than Pro/L, presumably due to the ability of cRGDyK peptide to enhance cellular uptake. The inhibitory effects of the procaine formulations on bEnd. 3 cells were also evaluated (Fig. 3B). The results revealed that the formulations had a weaker effect on the survival of the endothelial cells, which indicated the specific antitumor effects of procaine.

Transendothelial migration in a BBB model. The bEnd. 3 cells were used to establish a BBB model in vitro. The bEnd. 3 cells on the Transwell membrane in the donor chamber and the underlying layer of C6 cells on the plate from the acceptor chamber were collected, and the fluorescence intensity was measured using flow cytometry. The results revealed that the bEnd. 3 monolayer on the Transwell membrane internalized liposomes by cellular uptake (Figs. 3C and S1). The CFPE/cRGDyK-L formulation induced a significant increase in the fluorescence intensity of the $\mathrm{C} 6$ cells after penetrating the bEnd. 3 monolayer when compared with the CFPE/L formulation, which indicates that cRGDyK-L was transported across the bEnd.3 monolayer and delivered to the C6 cells. These results suggest that the transport of liposomes across the BBB model was enhanced when they were modified with cRGDyK peptide.
Wound closure and Transwell assays. Wound closure and Transwell assays were performed to investigate the effects of Pro/L and Pro/cRGDyK-L on C6 cell migration-. The results revealed that the Pro/cRGDyK-L formulation significantly suppressed the migration of C6 cells (Fig. 4A and B) in the wound healing assay compared with that in the control group. Similarly, the Transwell assay results confirmed that Pro/cRGDyK-L significantly inhibited the migration of C6 cells, with a stronger inhibitory effect than the Pro/L formulation (Fig. 4C and D). These results indicate that the suppressive effect of Pro/cRGDyK-L on glioma cell migration was superior to that of Pro/L.

Cell cycle and apoptosis detection assays. The effects of Pro/L and Pro/cRGDyK-L on the cell cycle and apoptosis of C6 glioma cells were investigated using flow cytometry. Notably, the results revealed that Pro/cRGDyK-L stimulated cell apoptosis in a concentration-dependent manner (Figs. 4E and S2). Interestingly, comparison with control cells revealed that Pro/L led to cell cycle arrest while treatment with Pro/cRGDyK-L resulted in increased cell cycle arrest at the G1 phase (Fig. 4F). These results indicate Pro/cRGDyK-L significantly stimulates glioma cell cycle arrest and apoptosis. 
A
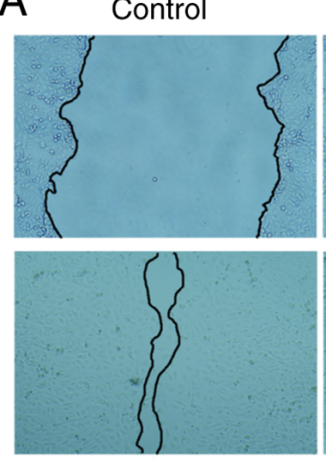

C

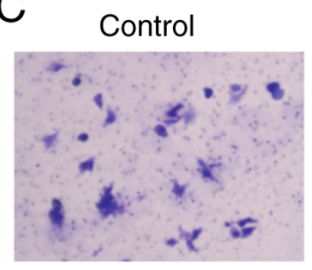

E
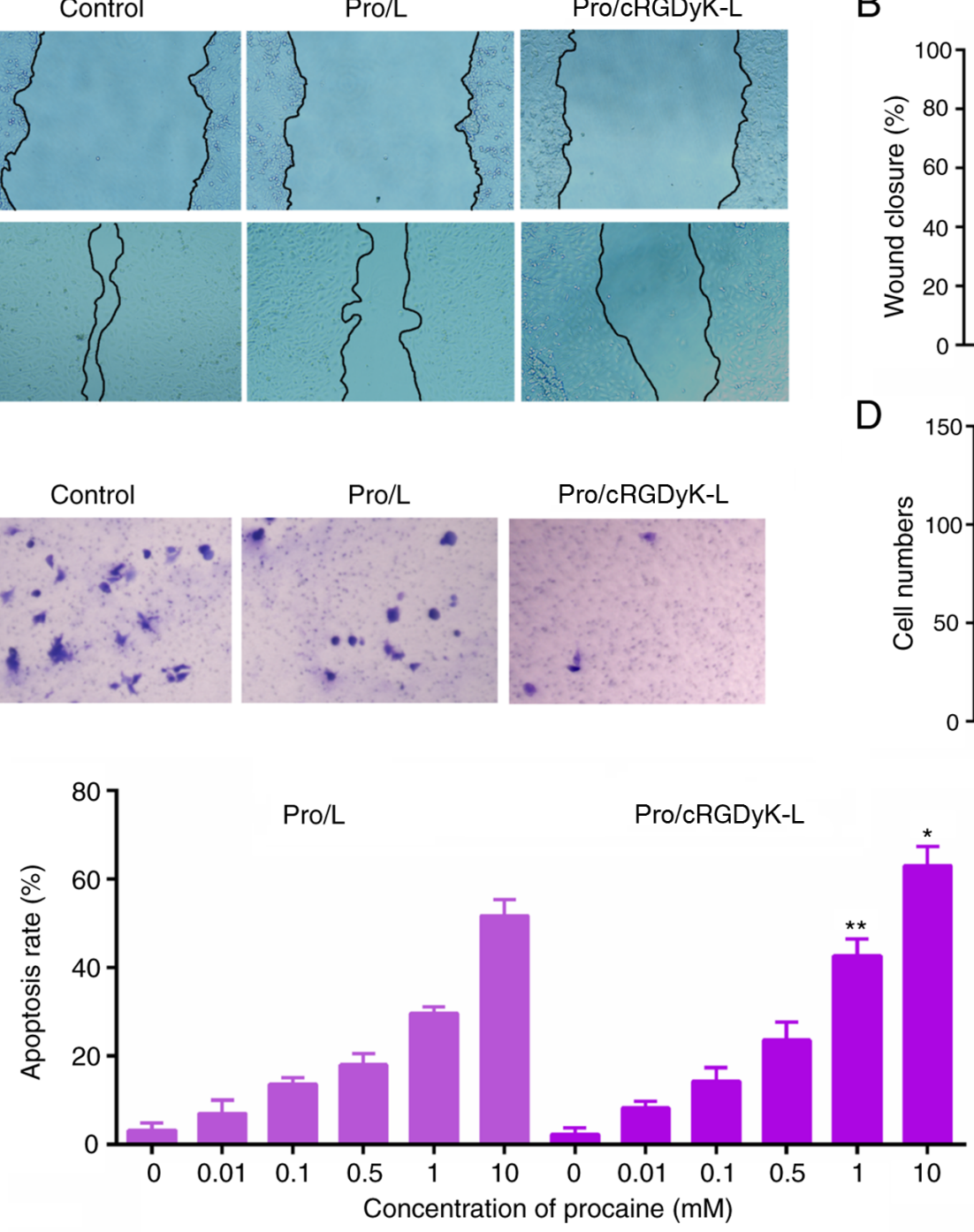

Pro/L

Pro/cRGDyK-L
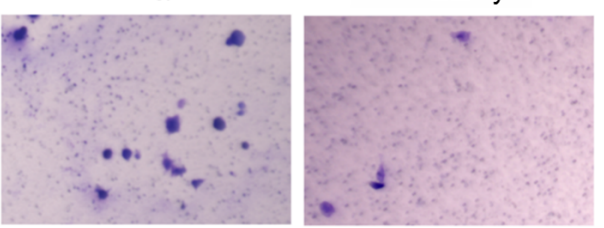

B
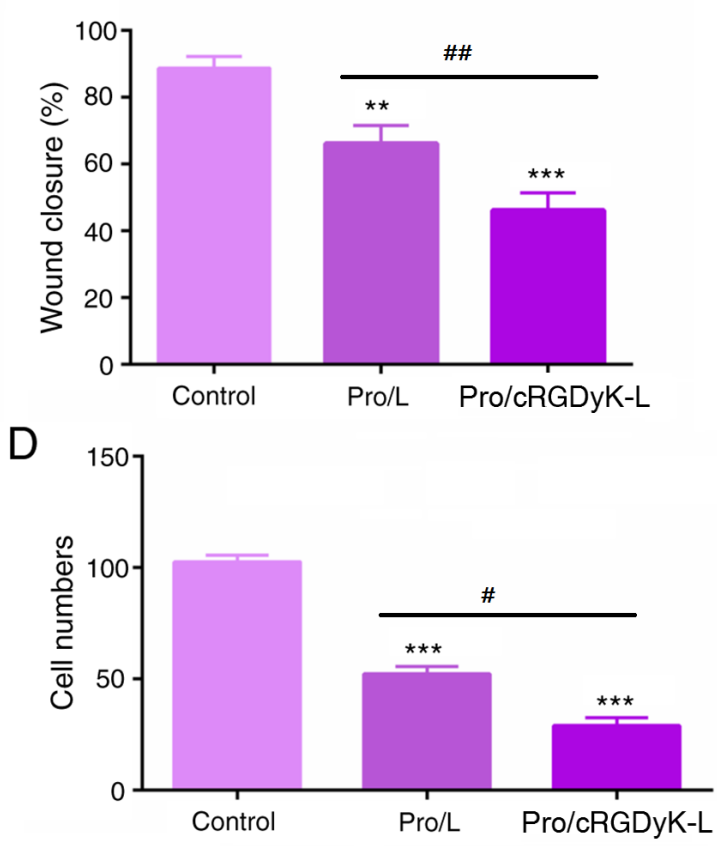

F
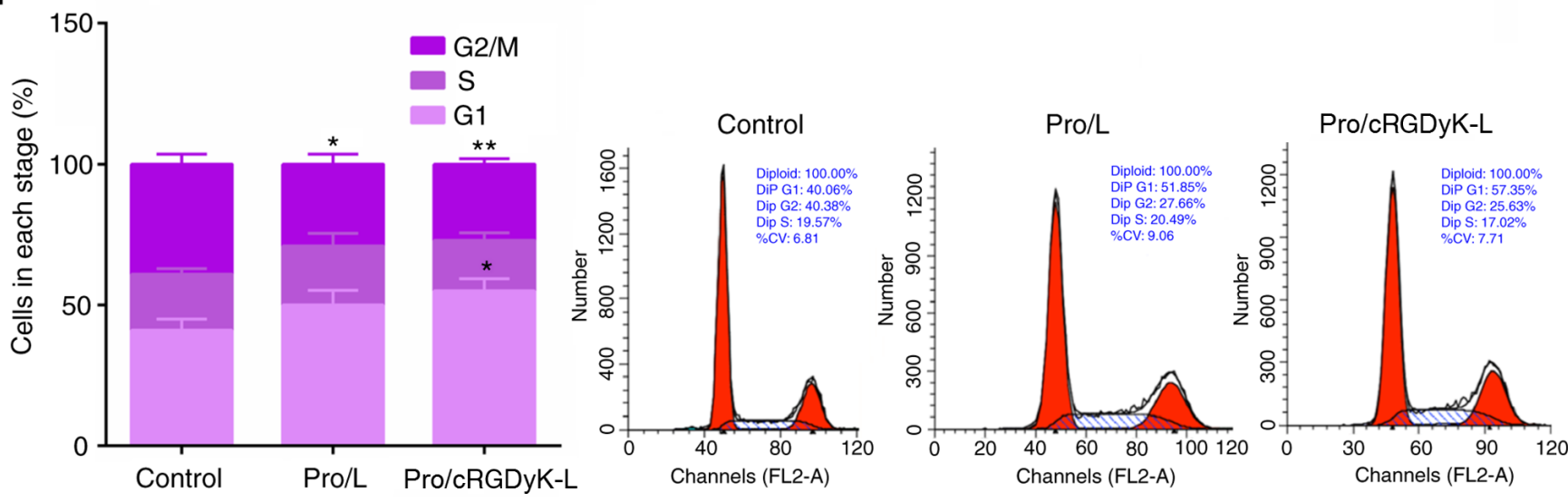

Figure 4. Effects of liposomal formulations on the migration, apoptosis and cell cycle of C6 cells. (A) Wound closure assay was performed to evaluate the migration of C6 cells following treatment with procaine-loaded liposomes (x100 magnification). (B) Quantitative analysis of the wound closure assay. (C) Transwell assays were performed to evaluate the migration of C6 cells (x100 magnification). (D) Cell number analysis in the Transwell assay. (E) Flow cytometry assays of Annexin V-FITC and PI staining were performed to evaluate apoptotic cells and the quantified apoptosis rates are shown. (F) Flow cytometry profiles representing the differences in cell cycle of $\mathrm{C} 6$ cells following treatment with procaine formulations. Results are presented as the mean \pm standard deviation $(\mathrm{n}=3){ }^{*} \mathrm{P}<0.05,{ }^{* *} \mathrm{P}<0.01,{ }^{* * *} \mathrm{P}<0.001$ vs. Control; ${ }^{*} \mathrm{P}<0.05,{ }^{\# *} \mathrm{P}<0.01$ vs. Pro/L. Pro, procaine; L, conventional liposome; cRGDyK-L, cRGDyK-modified liposome.

Pro/cRGDyK-L exhibits antitumor activity in glioma by targeting the ERK/p38MAPK pathway. The previous results demonstrate that Pro/cRGDyK-L can suppress the proliferation and migration of glioma cells and stimulate their apoptosis. By performing immunoblot assays, it was observed that the phosphorylation level of ERK was significantly 

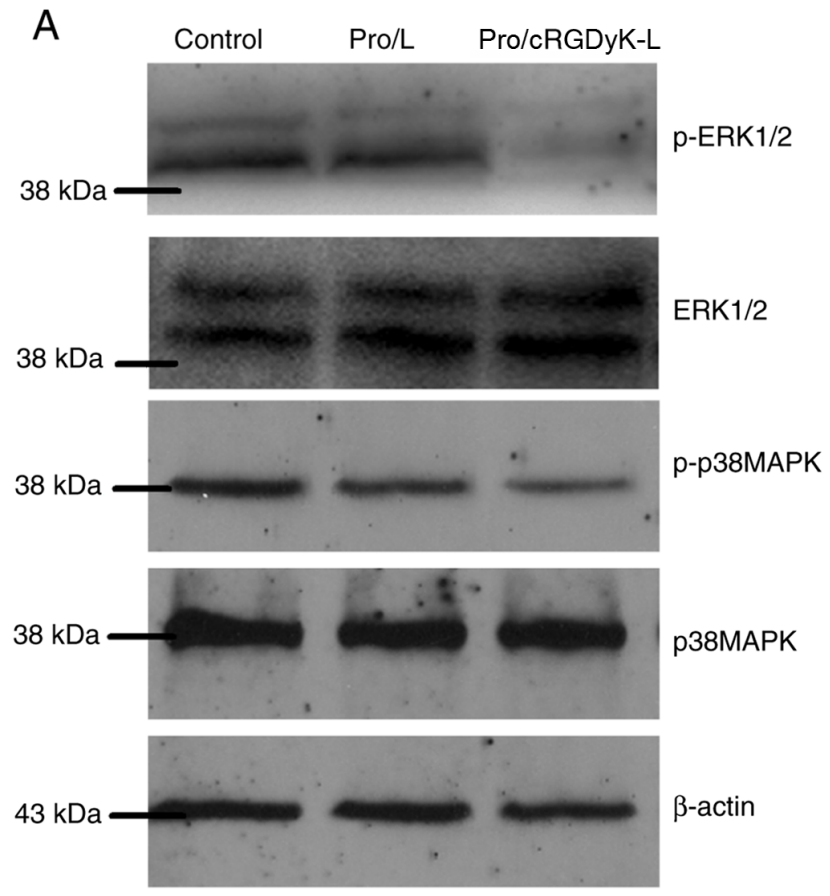

D

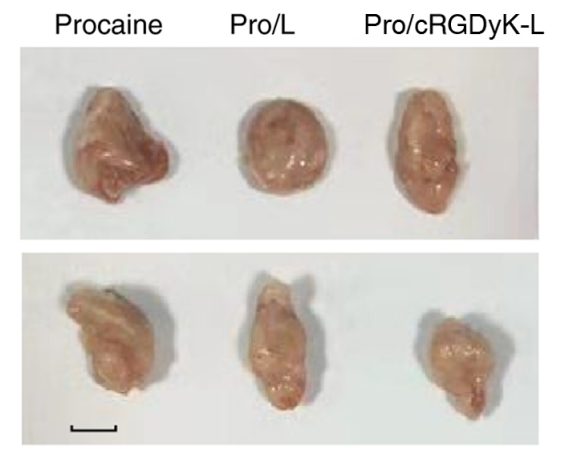

$\mathrm{F}$

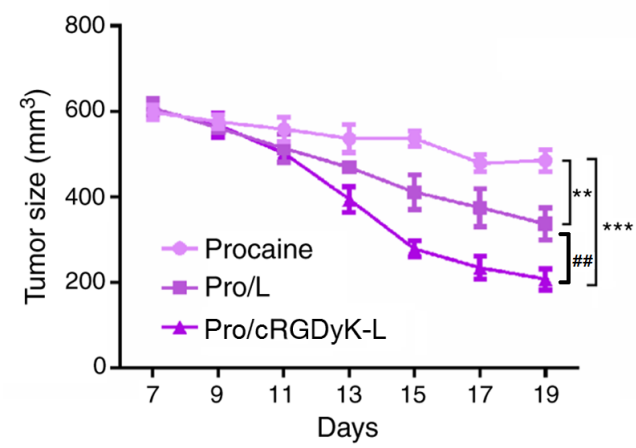

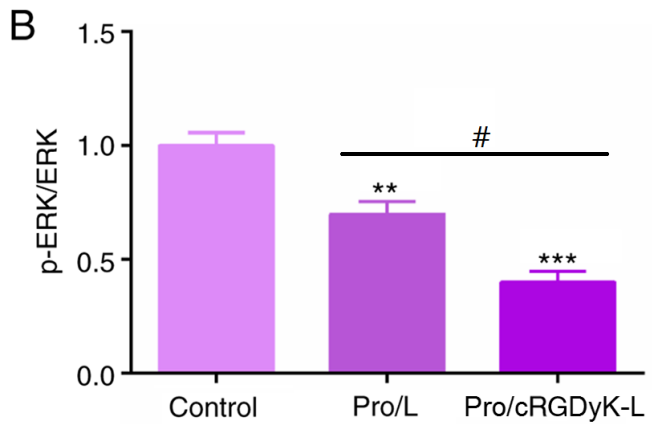

C

E
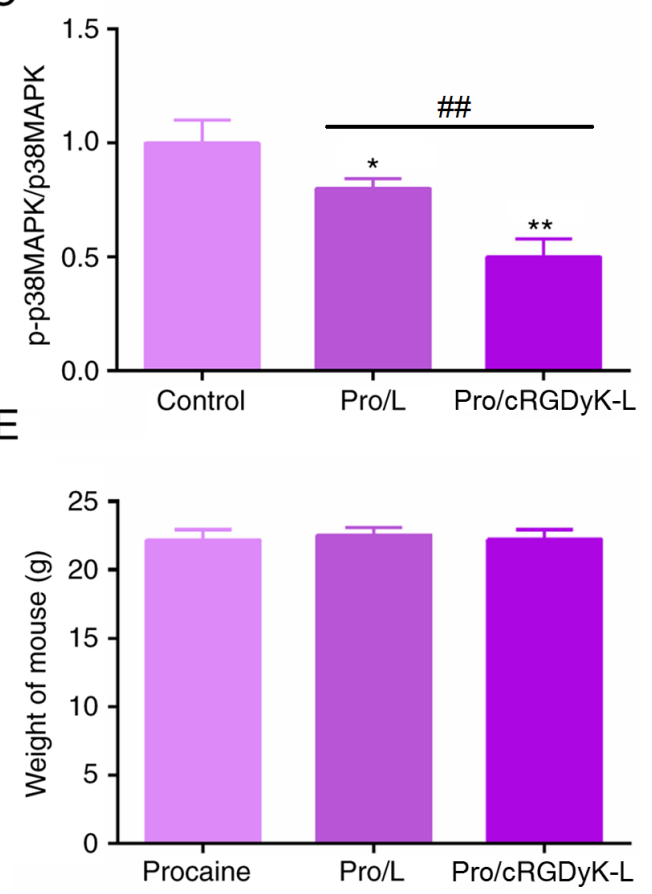

G

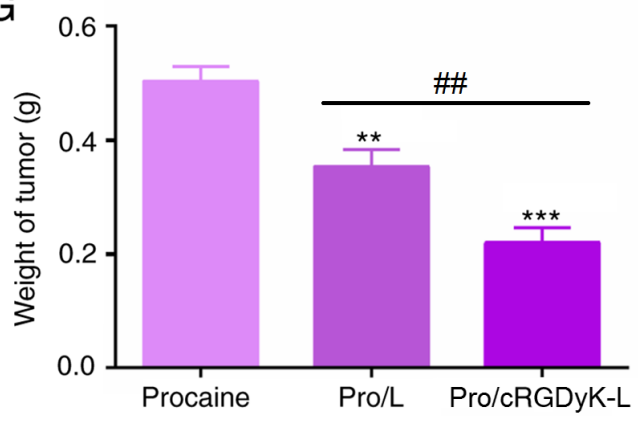

Figure 5. Mechanism of procaine-loaded liposomes in glioma cells and antitumor effects in vivo. (A) Western blotting assays showing the protein levels of p-ERK1/2, ERK1/2, p-p38MAPK, and p38MAPK following the treatment of C6 cells with procaine-loaded liposomes. Quantitative analysis of (B) p-ERK1/2/ERK1/2 and (C) p-p38MAPK/p38MAPK ratios. (D) Representative images of tumors formed from C6 cells in nude mice and treated with procaine formulations ( $\mathrm{n}=5 / \mathrm{group}$ ). Scale bar, $5 \mathrm{~mm}$. (E) Weights of the mice were measured. (F) Tumor growth curves of mice in the control and liposomal treatment groups are shown. (G) Weights of the tumors were measured. Results are presented as the mean \pm standard deviation. ${ }^{*} \mathrm{P}<0.05,{ }^{* *} \mathrm{P}<0.01,{ }^{* * * *} \mathrm{P}<0.001$ vs. Control; " $\mathrm{P}<0.05$, ${ }^{\# \prime} \mathrm{P}<0.01$ vs. Pro/L. Pro, procaine; L, conventional liposome; cRGDyK-L, cRGDyK-modified liposome; p-, phosphorylated.

decreased by treatment with Pro/cRGDyK-L and Pro/L, with Pro/cRGDyK-L exhibiting a stronger effect than Pro/L (Fig. 5A and B). Additionally, the results revealed that Pro/L treatment inhibited the phosphorylation of p38MAPK, and Pro/cRGDyK-L treatment decreased p38MAPK phosphorylation levels compared with those in the Pro/L treatment group (Fig. 5A and C). Therefore, it appears that Pro/cRGDyK-L exhibits antitumor activity in glioma by targeting the ERK/p38MAPK pathway.

The antitumor activity of Pro/cRGDyK-L was also confirmed in vivo. The findings from the xenograft assay demonstrate the effectiveness of this targeted therapy. The tumors observed in mice from the Pro/cRGDyK-L treatment group were smaller than those in the other two groups. 

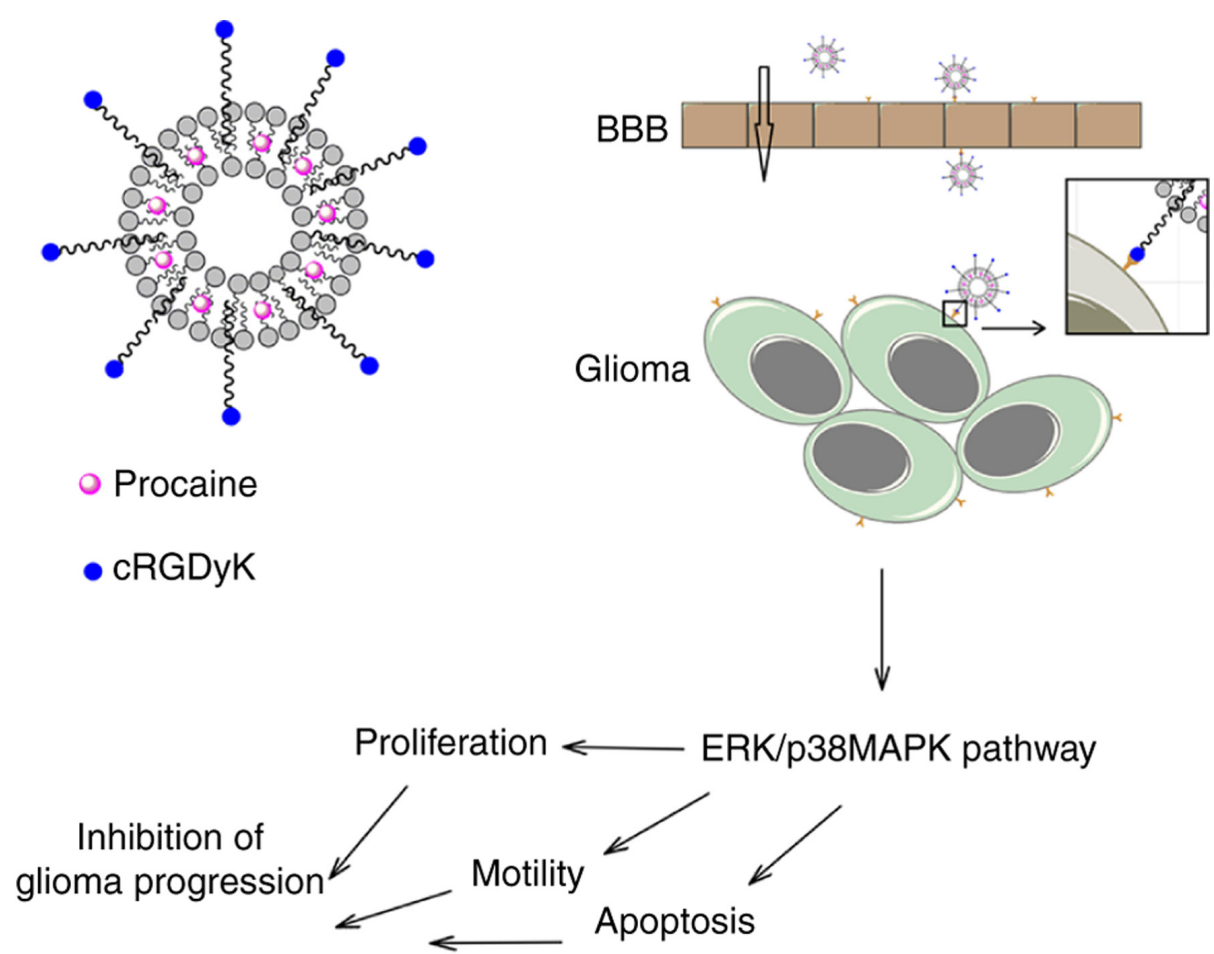

Figure 6. Schematic illustration of procaine-loaded cRGDyK-modified liposomes crossing the BBB and targeting glioma cells. BBB, blood-brain barrier.

Representative image of the tumors from each group are shown in Fig. 5D. Although there was no significant different in the weight of the mice in the three groups (Fig. 5E), the tumor volume (Fig. 5F) and weight (Fig. 5G) of the mice treated with Pro/cRGDyK-L were significantly reduced compared with those in the control group according to the tumor growth curves and tumor weight measurements, further demonstrating the antitumor effect of Pro/cRGDyK-L.

\section{Discussion}

Gliomas are the most common primary craniocerebral malignancies caused by cancerous changes in glial cells (26). The incidence rate of glioma among intracranial tumors is $35.2-61.0 \%$ (1). Notably, the incidence and recurrence rates of glioma are high, and the cure rate is low (27). However, due to the existence of the BBB, the invasion and metastasis of glioma is extremely low (27). However, existing therapeutic drugs are not adequate to meet clinical needs due to the BBB blocking their uptake into the brain (28). Therefore, it is urgently necessary to develop a novel strategy for targeted drug delivery to treat this particular malignancy.

Procaine is a type of local anesthetic (29). Procaine is used for local, regional and neuraxial anesthesia, and despite the emergence of several new anesthetic drugs, it remains a widely used anesthetic (30). Interestingly, procaine has also been revealed to have antitumor effects (31). A previous study indicated that procaine may serve as a specific DNA methylation inhibitor with antitumor effects in gastric cancer (31). Additionally, in other studies, procaine suppressed the proliferation and motility of colon cancer cells by suppressing the ERK/MAPK/FAK axis (32), and exhibited an inhibitory effect on osteosarcoma (33). These studies, together with the findings of the present study, indicate the potential role of procaine in tumor therapy.

In the present study, a cRGDyK-cholesterol derivative was designed and prepared, and used as a ligand in a liposomal drug delivery system. The procaine-loaded liposome Pro/cRGDyK-L was characterized for particle size, $\zeta$ potential, encapsulation efficiency, release profile, stability and hemolysis in vitro, and the results indicated the liposome had superior properties.

The present study also demonstrated that the Pro/cRGDyK-L formulation significantly enhanced the ability of procaine to penetrate the BBB and improve cellular uptake, and further revealed that it had strong effects on cell migration, induced apoptosis and led to cell cycle arrest. Notably, the present study also indicated that Pro/cRGDyK-L exhibited superior antitumor effects by targeting the ERK/p38MAPK pathway and inhibited tumor growth in vivo, as illustrated by the scheme in Fig. 6.

Tumor angiogenesis is an important factor that affects the prognosis of patients with tumors. During tumor growth, endothelial cells play a major role in the formation of new blood vessels that feed the tumor with nutrients (34). The results of the present study demonstrate that Pro/cRGDyK-L has an important effect on endothelial cells and thus may influence tumor angiogenesis and further affect tumor development.

In conclusion, with the aim of developing an efficient drug delivery system targeting glioma to improve the antitumor effect of procaine and explore its antitumor mechanism, a novel cRGDyK-cholesterol derivative was designed and synthesized for use in liposomes. The cyclic peptide markedly increase the ability of procaine to penetrate a model of the BBB and improved its cellular uptake. Additionally, the Pro/cRGDyK-L formulation exhibited strong inhibitory effects on cell 
migration, and also induced apoptosis and cell cycle arrest. The results further confirmed the superior antitumor effects of Pro/cRGDyK-L in vivo, which were mediated via targeting the ERK/p38MAPK pathway. Therefore, cRGDyK is indicated to be an effective ligand for BBB and glioma targeting, and the procaine-loaded liposome formulation Pro/cRGDyK-L exerts antitumor effects via targeting ERK/p38MAPK pathway and thereby suppresses tumor growth in mice.

\section{Acknowledgements}

Not applicable.

\section{Funding}

This study was supported by Science \& Technology Development Fund of Tianjin Education Commission for Higher Education (grant no. 2020KJ174).

\section{Availability of data and materials}

The datasets used and/or analyzed during the current study are available from the corresponding author on reasonable request.

\section{Authors' contributions}

DL, JG, CY and YW carried out the molecular biology experiments and drafted the manuscript. DL, JG, CY, BL, JS and MY participated in the design of the study and performed the statistical analysis. DL, HW and YL conceived the study, participated in its design and coordination and helped to draft the manuscript. All authors read and approved the final manuscript. DL and YL confirm the authenticity of all the raw data.

\section{Ethics approval and consent to participate}

All procedures performed in the current study were approved by the Laboratory Animal Ethics Committee of the Second Hospital of Tianjin Medical University.

\section{Patient consent for publication}

Not applicable.

\section{Competing interests}

The authors declare that they have no competing interests.

\section{References}

1. Comba A, Dunn PJ, Kish PE, Kadiyala P, Kahana A, Castro MG and Lowenstein PR: Laser Capture Microdissection of Glioma Subregions for Spatial and Molecular Characterization of Intratumoral Heterogeneity, Oncostreams, and Invasion. J Vis Exp 158: 10.3791/60939, 2020.

2. Zhang G, Ju H, Huang P, Yue P, Wan F and Dou C: Advances in gene therapy and viral therapy for glioma. J Clin Neurosurg 18 237-240, 2021

3. Lawrie TA, Gillespie D, Dowswell T, Evans J, Erridge S, Vale L, Kernohan A and Grant R: Long-term neurocognitive and other side effects of radiotherapy, with or without chemotherapy, for glioma. Cochrane Database Syst Rev 8: CD013047, 2019.
4. Eulitz J, Troost EGC, Raschke F, Schulz E, Lutz B, Dutz A, Löck S, Wohlfahrt P, Enghardt W, Karpowitz C, et al: Predicting late magnetic resonance image changes in glioma patients after proton therapy. Acta Oncol 58: 1536-1539, 2019.

5. Yang Z, Du Y, Sun Q, Peng Y, Wang R, Zhou Y, Wang Y, Zhang C and Qi X: Albumin-Based Nanotheranostic Probe with Hypoxia Alleviating Potentiates Synchronous Multimodal Imaging and Phototherapy for Glioma. ACS Nano 14: 6191-6212, 2020.

6. Patel D, Wairkar S and Yergeri MC: Current Developments in Targeted Drug Delivery Systems for Glioma. Curr Pharm Des 26: 3973-3984, 2020.

7. Ran D, Zhou J, Chai Z, Li J, Xie C, Mao J, Lu L, Zhang Y, $\mathrm{Wu} \mathrm{S}$, Zhan $\mathrm{C}$, et al: All-stage precisional glioma targeted therapy enabled by a well-designed D-peptide. Theranostics 10: 4073-4087, 2020.

8. Wang D, Yang T, Liu J, Liu Y, Xing N, He J, Yang J and Ai Y: Propofol Inhibits the Migration and Invasion of Glioma Cells by Blocking the PI3K/AKT Pathway Through miR-206/ROCK1 Axis. OncoTargets Ther 13: 361-370, 2020.

9. Li C, Xia M, Wang H, Li W, Peng J and Jiang H: Propofol facilitates migration and invasion of oral squamous cell carcinoma cells by upregulating SNAI1 expression. Life Sci 241: 117143, 2020.

10. Chang YC,Liu CL, Chen MJ,Hsu YW, Chen SN,Lin CH,Chen CM, Yang FM and $\mathrm{Hu}$ MC: Local anesthetics induce apoptosis in human breast tumor cells. Anesth Analg 118: 116-124, 2014.

11. Arita K, Utsumi T, Kato A, Kanno T, Kobuchi H, Inoue B, Akiyama $\mathrm{J}$ and Utsumi K: Mechanism of dibucaine-induced apoptosis in promyelocytic leukemia cells (HL-60). Biochem Pharmacol 60: 905-915, 2000.

12. Zhou H, Xu M, Luo G and Zhang Y: Effects of procaine on human nasopharyngeal carcinoma cell strain CNE-2Z. Lin Chung Er Bi Yan Hou Tou Jing Wai Ke Za Zhi 21: 1118-1121, 2007 (In Chinese).

13. Peifer C, Kinkel K, Abadleh M, Schollmeyer D and Laufer S: From five- to six-membered rings: 3,4-diarylquinolinone as lead for novel p38MAP kinase inhibitors. J Med Chem 50: 1213-1221, 2007.

14. Yang J, Zhang JN, Chen WL, Wang GS, Mao Q, Li SQ, Xiong WH, Lin YY, Ge JW, Li XX, et al: Effects of AQP5 gene silencing on proliferation, migration and apoptosis of human glioma cells through regulating EGFR/ERK/ p38 MAPK signaling pathway. Oncotarget 8: 38444-38455, 2017.

15. Rasheduzzaman M, Yin H and Park SY: Cardiac glycoside sensitized hepatocellular carcinoma cells to TRAIL via ROS generation, p38MAPK, mitochondrial transition, and autophagy mediation. Mol Carcinog 58: 2040-2051, 2019.

16. Zhao Y, Qu B, Wu X, Li X, Liu Q, Jin X, Guo L, Hai L and Wu Y: Design, synthesis and biological evaluation of brain targeting 1-ascorbic acid prodrugs of ibuprofen with 'lock-in' function. Eur J Med Chem 82: 314-323, 2014.

17. Singh I, Swami R, Jeengar MK, Khan W and Sistla R: p-Aminop henyl- $\alpha$-D-mannopyranoside engineered lipidic nanoparticles for effective delivery of docetaxel to brain. Chem Phys Lipids 188: 1-9, 2015.

18. Qiu L, Hu Q, Cheng L, Li L, Tian C, Chen W, Chen Q, Hu W, $\mathrm{Xu} \mathrm{L}$, Yang J, et al: cRGDyK modified $\mathrm{pH}$ responsive nanoparticles for specific intracellular delivery of doxorubicin. Acta Biomater 30: 285-298, 2016.

19. Yuan ZQ, Li JZ, Liu Y, Chen WL, Yang SD, Zhang CG, Zhu WJ, Zhou XF, Liu C and Zhang XN: Systemic delivery of micelles loading with paclitaxel using N-succinyl-palmitoyl-chitosan decorated with cRGDyK peptide to inhibit non-small-cell lung cancer. Int J Pharm 492: 141-151, 2015.

20. Zhao Z, Zhao Y, Xie C, Chen C, Lin D, Wang S, Lin D, Cui X, Guo $\mathrm{Z}$ and Zhou J: Dual-active targeting liposomes drug delivery system for bone metastatic breast cancer: Synthesis and biological evaluation. Chem Phys Lipids 223: 104785, 2019.

21. Qiu Y, Yu Q, Liu Y, Tang J, Wang X, Lu Z, Xu Z and He Q: Dual Receptor Targeting Cell Penetrating Peptide Modified Liposome for Glioma and Breast Cancer Postoperative Recurrence Therapy. Pharm Res 35: 130, 2018.

22. Yang Y, Zhao Z, Xie C and Zhao Y: Dual-targeting liposome modified by glutamic hexapeptide and folic acid for bone metastatic breast cancer. Chem Phys Lipids 228: 104882, 2020.

23. Belhadj Z, Ying M, Cao X, Hu X, Zhan C, Wei X, Gao J, Wang X, Yan Z and Lu W: Design of Y-shaped targeting material for liposome-based multifunctional glioblastoma-targeted drug delivery. J Control Release 255: 132-141, 2017. 
24. Zhao Z, Chen C, Xie C and Zhao Y: Design, synthesis and evaluation of liposomes modified with dendritic aspartic acid for bone-specific targeting. Chem Phys Lipids 226: 104832, 2020.

25. Yue H, Xie K, Ji X, Xu B, Wang C and Shi P: Vascularized neural constructs for ex-vivo reconstitution of blood-brain barrier function. Biomaterials 245: 119980, 2020.

26. Radünz M, Hackbart HCDS, Bona NP, Pedra NS, Hoffmann JF, Stefanello FM and Da Rosa Zavareze E: Glucosinolates and phenolic compounds rich broccoli extract: Encapsulation by electrospraying and antitumor activity against glial tumor cells. Colloids Surf B Biointerfaces 192: 111020, 2020.

27. Delgado-López PD and Martín-Alonso J: Prophylactic anticonvulsant therapy in high-grade glioma: A systematic review and meta-analysis of longitudinal studies. Neurocirugia (Astur : Engl Ed) 31: 268-278, 2020 (In English, Spanish).

28. Lübtow MM, Oerter S, Quader S, Jeanclos E, Cubukova A, Krafft M, Haider MS, Schulte C, Meier L, Rist M, et al: In Vitro Blood-Brain Barrier Permeability and Cytotoxicity of an Atorvastatin-Loaded Nanoformulation Against Glioblastoma in 2D and 3D Models. Mol Pharm 17: 1835-1847, 2020.

29. Zhao X, Qi T, Yang M, Zhang W, Kong C, Hao M, Wang Y Zhang H, Yang B, Yang J, et al: Synthesis of dual functional procaine-derived carbon dots for bioimaging and anticancer therapy. Nanomedicine (Lond) 15: 677-689, 2020.
30. Dunaway SB, Maxwell CL, Tantalo LC, Sahi SK and Marra CM Neurosyphilis Treatment Outcomes After Intravenous Penicillin G Versus Intramuscular Procaine Penicillin Plus Oral Probenecid. Clin Infect Dis 71: 267-273, 2020.

31. Li YC, Wang Y, Li DD, Zhang Y, Zhao TC and Li CF: Procaine is a specific DNA methylation inhibitor with anti-tumor effect for human gastric cancer. J Cell Biochem 119: 2440-2449, 2018.

32. Li C, Gao S, Li X, Li C and Ma L: Procaine Inhibits the Proliferation and Migration of Colon Cancer Cells Through Inactivation of the ERK/MAPK/FAK Pathways by Regulation of RhoA. Oncol Res 26: 209-217, 2018.

33. Ying B, Huang H, Li H, Song M, Wu S and Ying H: Procaine Inhibits Proliferation and Migration and Promotes Cell Apoptosis in Osteosarcoma Cells by Upregulation of MicroRNA-133b. Oncol Res 25: 1463-1470, 2017.

34. Jiang W and Wang M: New insights into the immunomodulatory role of exosomes in cardiovascular disease. Rev Cardiovasc Med 20: 153-160, 2019.

This work is licensed under a Creative Commons Attribution-NonCommercial-NoDerivatives 4.0 International (CC BY-NC-ND 4.0) License. 